\title{
THE NECESSITY OF A PROFESSIONAL \\ MEDIATION IN EDUCATIONAL SETTINGS
}

\author{
A NECESSIDADE DA MEDIAÇÃO PROFISSIONAL NO AMBIENTE EDUCATIVO
}

\section{LA NECESIDAD DE LA MEDIACIÓN PROFESIONAL EN EL ENTORNO EDUCATIVO}

\author{
Jan Breuer ${ }^{1}$ \\ Ulrike Buchman ${ }^{2}$
}

\begin{abstract}
Society is based on human participation in society and the individual's understanding of the same. Discussing the matter of participation in society, this article focuses on the issue of the individual human being, that is - in a philosophical understanding - called Subject. The Subject is integrated in an individual social surrounding. Being able to participate in society means to learn about the society, the social surrounding, and the Subject's internalised concept of the social surrounding. The confrontation the Subject is forced to deal with, for example by transformations of the social surrounding, is a very complex process that is called mediation. The mediation may be the key to gain a better understanding of what it means to be a Subject, of the society, and of educational processes that need to be mediated by the Subject. Therefore, the right to education means to discuss the Subject's participation in society as well as the professional mediation in educational settings.
\end{abstract}

KEYWORDS: Subject. Object. Social surrounding. Internalised concept. Mediation. Gente.

ZUSAMMENFASSUNG: Die Gesellschaft ist geprägt von der menschlichen Teilnahme an Gesellschaft und dem individuellen Verständnis/Bewusstsein von Gesellschaft. Ausgehend vom Individuum - im philosophischen bezeichnet als Subjekt - wird im Folgenden die Teilnahme an Gesellschaft thematisiert. Das Subjekt ist dabei integriert in einen individuellen Sozialraum mit einer je subjektspezifischen Einbindung/Konstitution. An Gesellschaft teilzunehmen bedeutet daher sich auseinander zu setzen mit der Gesellschaft, dem Sozialraum und dem subjektiven, internalisierten Konzept des Sozialraums, d. h. der Lebenswelt. Die Bewältigung von Konfrontationen, die das Subjekt in diesem Kontext zu leisten hat - zum Beispiel aufgrund von Transformationen des Sozialraums - ist ein komplexer Prozess, der kategorial als Vermittlung gefasst ist. Die Vermittlung ist daher als Schlüssel zu einem besseren Verständnis vom Subjekt, der Gesellschaft und von Bildungsprozessen, die jeweils eine Vermittlung seitens des Subjekts voraussetzen, anzusehen. Aufgrund dessen ist das Recht auf Bildung zu verstehen als: a) die Teilnahme des Subjekts an Gesellschaft, und b) die professionelle Vermittlung zwischen Sozialraum und Lebenswelt durch das Subjekt, die notwendige Voraussetzung ist für gesellschaftliche Teilnahme und das Gelingen von Bildung.

KEYWORDS: Subjekt. Objekt. Sozialraum. Lebenswelt. Vermittlung. Gente.

RESUMÉN: La sociedad se basa en la participación humana en la sociedad y cómo el individuo entiende la misma. Reflexionando sobre el tema de la participación en la sociedad, el presente artículo se centra en el ser humano como individuo, en el sentido filosófico conocido como Sujeto. El Sujeto se integra en un entorno social individual. El ser capaz de participar en la sociedad significa aprender sobre la misma, el entorno social y el concepto internalizado del Sujeto de entorno social. La confrontación a la que el Sujeto debe enfrentarse, por ejemplo las transformaciones de los entornos sociales, es un proceso muy complejo llamado mediación. La mediación puede ser la clave para conseguir un mejor entendimiento de lo que significa ser Sujeto, de la sociedad y de los procesos educativos con los que el Sujeto tiene que mediar. En consecuencia, el derecho a la

Submetido em: 14/08/2017 - Aceito em: 08/02/2018 - Publicado em: 12/02/2018.

\begin{tabular}{l|c|c|c|c|c|c|} 
(C) Rev. Educ. Perspec. & Viçosa, $M G$ & v.8 & n.3 & p.414-425 & set./dez. 2017 & eISSN 2178-8359 \\
\hline
\end{tabular}


educación debe referirse a la participación del Sujeto en la sociedad, así como la mediación profesional del entorno educativo.

PAlABRAS Clave: Sujeto. Objeto. Entorno social. Concepto internalizado. Mediación. Gente.

\section{THE NECESSITY OF A PROFESSIONAL MEDIATION IN EDUCATIONAL SETTINGS}

Checking my Facebook account, something I usually do maybe once a month, a post that showed one part of a newspaper article circled in red, got my attention. The article was originally published by Correio Popular, RAC, Campinas on July, the 11th 2017. The marked sentence was the reason of a huge discussion between Facebook users. Searching the internet to find the whole article and try to make my own opinion about the topic, I realised that Débora Bertoldi, the article's author, is not a newspaper journalist but a newspaper reader that published her own point of view with the title "A realidade da Campinas rural". As usual, the comments on Facebook in relation to the post, show understanding and misunderstanding, agreement and disagreement, personal concerns as much as fears and the view for new possibilities. I tried to understand the reasons for this controversial discussion and realised, that they are related to the peoples individual social surrounding and their internalised concept of the social surrounding. The sentence of discussion says: "Como continuo a produzir se a mão de obra não quer mais saber de trabalhar com a enxada porque prefere estudar e depois ter empregos que permitem melhores salários?" ('How can I continue to produce when the worker does not want to know anymore how to work with the hoe because he prefers to study at University and, after graduating, getting a good job allowing a better salary?', translated by the authors).

I will try to explain the sentence of discussion within a concept that looks at the implications of an individual's social surrounding and its internalised concept of the surrounding. To enable a better understanding, I will discuss the concept in relation to the research results from Janice Perlman, published 2010 in "Favela - Four Decades of Living on the Edge in Rio de Janeiro", developed during 40 years of questioning Favela residents and analysing political as well as economical transformations in Rio de Janeiro and Brazil. Perlman presents in her study the life, the lifestyle and the circumstances of 750 Favela residents in 1968/69 and was able to compare these results in 2008/09 to 41 percent of the original interviewees, as much as their children and grandchildren (PERLMAN, 2010, p. 18). The study shows perfectly the differences in the social surrounding and the internalised concept of the world, including a great variety of possible consequences for the individual's development and success in life within this implication.

\begin{tabular}{l|c|c|c|c|c|c|} 
(C) Rev. Educ. Perspec. & Viçosa, $M G$ & v.8 & n.3 & p.414-425 & set./dez. 2017 & eISSN 2178-8359 \\
\hline
\end{tabular}


Let us begin with the Favela interviewees who migrated from the countryside to the cities in the 1960s. Most of them grew up as children of fishermen or farmers. The way we face Education nowadays, as institutional education - a teacher/professional pedagogue educates a group of students - was not common. "The only functioning institution was a chaotic oneroom schoolhouse. [...] I am fairly certain that no one learned to read in that school" (PERLMAN, 2010, p. XVI). They learned from their parents what is necessary to participate in society or at least what is necessary to know to fish or to farm. This relationship between educator and learner, compared to institutional education, is called functional education.

Following the argumentation of Perlman, the former countryside residents in Brazil did not know much about the world beyond their own social surrounding. The social surrounding includes the people they deal with, the surrounding they interact with, the objects they use to interact and all structures that characterize the surrounding. This includes the metaphysical world as well as the social definitions of the world. Growing up in society means to learn about the metaphysical objects and the definitions of their use, behaviour, denomination, etc. given by society. Socialization is the scientific word describing this process.

According to Arendt (1971) all human beings are able to sense the metaphysical world by hearing, speaking, tasting, smelling and touching anthropologically. But in comparison to animals, humans do not react instinctively to something they sense; they have a desire to understand what they sense (ARENDT, 1971, p. 59). This desire to understand the surrounding, "a sixth sense" (ARENDT, 1971, p. 59), transfers all sensed objects to an inner world, a world where humans are able to think about the true nature of the sensed objects. In this philosophical concept Socialisation can be understood as the transfer of Objects and their social meaning to an individual inner world. This inner world is the source of all motivations, ideas, creativity; it characterizes the personality and individuality and effects the way of interaction with the surrounding.

A similar argumentation is given by Lisop and Huisinga (2004), although they focus on an educational understanding. They argue that the Subject is one that needs to balance between two sides, one somato-psychological, the other psycho-social, and all implicated relations within. Both sides do interact through the human senses, but in contrast to Arendt (1971) it is not thought to transfer all sensed objects in an inner world that is independent of the senses. The senses do mediate between both sides and this ability to mediate is the fact that characterises the human being as a Subject. The somato-psychological side refers to the human necessities and instincts; the psycho-social side refers to the individual in relation to the society. Dealing with both sides that confront each other, mediating between both sides and deciding for one side or the other depending the situation, is the task all humans are

\begin{tabular}{l|c|c|c|c|c|c|} 
(C) Rev. Educ. Perspec. & Viçosa, $M G$ & v.8 & n.3 & p.414-425 & set./dez. 2017 & eISSN 2178-8359 \\
\hline
\end{tabular}


forced to do living in society. Sometimes this task is done without consciousness, other times we are well aware about possible conflicts and decide - depending on the situation -in favour for one or the other side.

Dealing with the conflicts that occur between the somato-psychological and the psycho-social necessities, is a process, that a human being needs to learn to survive in society. It is a lifelong process and deciding in favour of one side or the other is never good or bad. It always depends on the situation, the social surrounding, the Subject's internalised concept of the world, ... or in the words of Lisop and Huisinga: it always depends on the interaction between the somato-psychological and the psycho-social side of the Subject. Referring to the confrontation and the act of mediation, it does not matter if we follow a concept of six senses (ARENDT, 1971) or a concept of twelve senses (LISOP; HUISINGA, 2004). The essential point is that all humans are able to sense the surrounding and that they have a desire to understand the surrounding, to be part of the surrounding. Applying this concept to the data provided by Perlman, the process of Socialization must be examined, or more precisely, the internalised concept of the world and the social surrounding of the original interviewees.

Growing up on the Brazilian countryside in the 1950/60s does not only mean to be educated functionally, but also to be in a social surrounding that is characterised by a fight to survive, by a strong family spirit, by "sharing equally when the saveiros and jangadas (fishing boats) returned with the catch of the day" (PERLMAN, 2010, p. XVI). These characterizations of the social surrounding shape the individual's concept of the world inextricably. Understanding the world, understanding the sensed surrounding implies the transfer of the sensed Objects to an internalised concept of the world. The internalised concept is something very individual and is the sensed and transferred reality of the social surrounding belonging to one Subject, the Subject of these special senses and surrounding. Another Subject has another concept of the world, it senses the social surrounding another way and considers other aspects as true or false, good or bad, real or illusive. For the original interviewees the life in rural areas was the only life they knew and was the only concept of the world they had. They did not have an understanding of another world, a world beyond their own concept of the world, except maybe a travelling tradesman who told them about the life in the big cities on his way through the rural areas. In that case the told stories of the life in the cities were probably taken as tales, maybe they even created wishes to have a similar life, but until then, the wishes were only wishes, similar to the wish to have a good catch of the day. The moment this changed was the moment when the radio appeared in the rural areas.

The radio - the most important technological development of that time - got affordable for the majority of the population in the 1960s and transmitted the life of the "big city", where

\begin{tabular}{l|l|l|l|l|l|l} 
(C) Rev. Educ. Perspec. & Viçosa, $M G$ & v.8 & n.3 & p.414-425 & set./dez. 2017 & eISSN 2178-8359 \\
\hline
\end{tabular}


they were located. The every-day confrontation of the own internalised concept of the world created by the social surrounding with a good life in the cities, with a good health system, with many jobs, with a good infrastructure, etc. created a disbalance between the individual's concept of the world and the concept of the world beyond. The former wish of a better life became a desire of a better life, a desire to achieve a life as the one transmitted by the radio. This desire became an eagerness so powerful that many people gave up their life in the rural areas and moved to the cities in expectation of a better life, expecting a better quality and style of life.

[...] the transistor radio had appeared. It was the first time that most of the people heard directly about life beyond the parameters of their village. The technology that enabled music and messages, word images and information to be carried on airwaves into otherwise inaccessible places changed life options from that moment on. The opening of new horizons - for better or worse - beckoned people to the 'bright lights, big city'. Young people were no longer content to spend their lives fishing, hoping to die in the arms of Yemanjá, the seductive goddess of the waters or to work the land with the hoe, as their families had always done (PERLMAN, 2010, XVI).

It is the expectation of a better life that leads the people to change their lifestyle, that motivates people to learn expansively (HOLZKAMP, 1985), that is, in combination with curiosity, the human motion to understand the sensed Objects. "They were attracted to the excitement of the unknown - they wanted to go where the (movimento) action was" (PERLMAN, 2010, p. XVI). Getting to the city without money, without any option to find a shelter, forced people to "build shacks and eventually settlements on vacant lands, typically on steep hillsides, or morros, or in flood-prone swamps. Thus the favelas grew from tiny settlements into larger communities with distinctive personalities" (PERLMAN, 2010, p. XVIII).

The desire for a better life pushed people to adapt to the new surrounding in the cities. This adaption means, in the concept of Subject and Object, to adapt the individual's concept of the world - shaped by the life in rural areas - to a new social surrounding in an urban area that does not fit to the already existing internalised concept of the world of these people, or vice versa. According to Perlman "the people adapted rapidly and astutely to the city and developed creative coping mechanisms to deal with the challenges they faced. The problem was that the city did not adapt to them" (PERLMAN, 2010, p. XVIII).

Every coping mechanism is a mechanism that comes into effect when the Subject is forced to deal with new Objects, when the individuals concept of the world does not fit to the social surrounding. The coping mechanism tries to mediate between the new sensed circumstances and the new circumstances which do not fit to the internalised concept of the world; they try

\begin{tabular}{l|l|l|l|l|l|l} 
(C) Rev. Educ. Perspec. & Viçosa, $M G$ & v.8 & n.3 & p.414-425 & set./dez. 2017 & eISSN 2178-8359 \\
\hline
\end{tabular}


to defend the internalised concept of the world, or according to the view of the psychoanalysis, they try to defend the ego (Ich) in relation to the id (Es) and the superego (Über-Ich). These coping mechanisms can be repression (Verdrängung), reversal into the opposite (Verkehrung ins Gegenteil), denial (Verleugnung), isolation (Isolierung), projection (Projektion), shift (Verschiebung) or regression (Regression) (LISOP; HUISINGA, 2004). As an example, Perlman describes without any specification of the coping mechanism:

As in all of the communities I studied, each sub-area thinks that the other areas are more dangerous. They all say, 'Aqui é tudo tranquilo - lá é muito perigoso' ('here it is very peaceful - over there it is very dangerous'). That seems to be just one of many coping mechanisms for getting through each day (PERLMAN, 2010, p. 136).

Intuitively, it is fair to say that the people moving to the cities need to change their internalised concept of the world. But changing this concept is not as easy as it sounds. It requires acceptance to give up what was previously valid, what was previously leading to success in life, but now, in a new social surrounding, is obsolete. This acceptance is painful and in general, human beings try to avoid pain. That is the reason why coping mechanism do not influence the internalised concept of the world and why an internalised concept, once shaped, does accompany a Subject all lifelong. It is part of the human identity.

Changing the internalised concept of the world in the way that it fits to the new circumstances needs a highly-professional pedagogical support offering alternative approaches. A direct confrontation with the new reality, a direct argumentation to give up obsolete routines and structures; all direct approaches in general lead to coping mechanism and do not engage the internalised concept of the world. In other words: direct approaches are threats to the Subjects' identity and the Subjects' concept of the world. This is the research result of several projects using alternative approaches as Mapping (BUCHMANN; GIMBEL, 2015; GIMBEL, 2017), Tagging (BUCHMANN, 2013) or Casting (BUCHMANN; DIEZEMANN, 2014).

Starting a new life in a Favela with a rural concept of the world is according to Perlman "a nonissue" (PERLMAN, 2010, p. XVIII). This nonissue is due to the valid routines and structures they have in their internalised concept of the world, that they can apply to their new social surrounding. These valid routines and structures are visible in the description of the life in the Favelas in 1968-69:

The community was poor, but people mobilized to demand improved urban services, worked hard, had fun, and had hope. They watched out for each other, and daily life had a calm, convivial rhythm. When I returned in 1999, the physical infrastructure and house-hold amenities were greatly improved. But where there had been hope, now there were fear and uncertainty. People were afraid of getting killed in the crossfire during a drug war between competing gangs, afraid that their

\begin{tabular}{l|c|c|c|c|c|c|} 
(C) Rev. Educ. Perspec. & Viçosa, $M G$ & v.8 & n.3 & p.414-425 & set./dez. 2017 & eISSN 2178-8359 \\
\hline
\end{tabular}


children would not return alive after school, or that a stray bullet would kill their toddlers playing on their verandas (PERLMAN, 2010, p. xxi-xxii).

Working hard, having fun and hope, watching out for each other and following a calm and convivial rhythm of life are attributes that were part of their process of Socialisation, that were part of their concept of the world, that were valid in rural areas and applicable to urban areas. These valid attributes are 'nonissues' to start a new life in a Favela and, in addition, they shaped the new social surrounding, the Favela, essentially by modifying parts of the surrounding in the way that it fits to their understanding of the world, to their internalised concept. This shows that the modification of the internalised concept of the world is a very complex process, often avoided by developing coping mechanism and/or the stimulus to modify the social surrounding. In fact, our internalised concept is part of what we are, is part of our identity.

One example of what happens when neither coping mechanism, nor the modification of the social surrounding are possible, is described by Margarida in an interview with Perlman concerning the expulsion and demolition of Catacumba in 1970:

We cried day after day. We didn't even know where our families and friends were. Many got sick. Some became alcoholics. Several older people died - they say it was stress or high blood pressure, but I think they died of broken hearts [...]. We were not kept together as a community; no, it was a mixture of people from other favelas - we didn't know each other - we didn't trust each other [...]. We lost our identity. We lost who we were within our communities. We were nobodies" (PERLMAN, 2010, p. 83).

It is painful: the loss of identity, the loss of the social surrounding, the loss of the validity of the internalised concept of the world. The pain is what forces the Subject to modify the internalised concept of the world and enables the Subject to adapt to a new social surrounding. "Over time people adapted to their new environment. They found jobs closer to their new homes, made new friends, and began to create social organizations" (PERLMAN, 2010, p. 86). This evidence refers to the complex processes of modification and adaption within the insoluble implication of the social surrounding and the internalised concept of the world, that needs to be mediated. In other words: mediation is the process implicating modification and adaption. But, is it really the modification of the internalised concept of the world what enables people to adapt to the new social surrounding? Or is it only another coping mechanism, created to adapt to the new social surrounding? Maybe the following phenome, identified by Perlman, gives a clue to the answer.

One of the phenomena Perlman describes is the fact that the lives of the interviewees do not change in a clear pattern in relation to the transformations of the social surrounding, described as macro-level changes. As a Sociologist, she describes:

\begin{tabular}{l|c|c|c|c|c|c} 
(C) Rev. Educ. Perspec. & Viçosa, $M G$ & v.8 & n.3 & p.414-425 & set./dez. 2017 & eISSN 2178-8359 \\
\hline
\end{tabular}


No clear pattern emerged. This lack of a correspondence between macro-level changes and changes in the lives of those we interviewed might be attributable to gaps in the interviewees' memories or their failure to make connections between larger trends and family fates. Likewise, it could be due to simple methodological flaws and/or to the overwhelming number of intervening variables (PERLMAN, 2010, p. 261).

The two patterns Perlman is able to identify as a direct influence to the lifestyle and quality of life of the interviewees are the status of employment and the consequences of the Real Plan that increased the purchasing power of all people in Brazil in the 1990s. The philosophical and educational concept we discussed so far, may enable us to have a closer look to the very complex and individual processes of mediation between social surrounding and internalised concept of the world, that do not allow a clear pattern between macro-level changes and changes in the interviewees lives.

It is a fact, that the interviewees adapted to their new social surrounding. Considering that Perlman interviewed twice over 750 people, a fluctuation between the data is to be expected. In case the adaption to the new social surrounding is due to the modification of the internalised concept of the world, a clear pattern should emerge. This pattern would probably be characterized by no kind of confrontation of the internalised concept with the new social surrounding of the interviewees, because they adapted their internalised concept, in order not to deal with confrontation anymore. All these resulting in an improvement of lifestyle and quality and the oblivion or disregard of the old life, the old social surrounding and the social surrounding before. But that seems to be very implausible. It would mean a change of identity and the oblivion of who they were/are. This is maybe the result of an illness or an accident, but usually does not occur to otherwise healthy people. Therefore, the modification of the internalised concept of the world does not seem to be logical, leading to a coping mechanism that enabled people to adapt to the new social surrounding. This poses one central question in educational settings: Is it possible to modify the once-shaped and internalised concept of the world? What kind of representation enables to modify and shape, maybe even re-shape, the internalised concept of the world? Is it possible at all? So far there are no reliable data to these questions.

After looking at the original interviewees in Perlmans study, the social surrounding and internalised concept of the world from the children and grandchildren of the original interviewees will be analysed and the essential differences between both will be presented.

Whereas their grandparents, original migrants to Rio, were happy to do any type of work for any level of pay, their children and their children's children expect more. They are not gente humilde from the roça (countryside) but astute observers of the urban scene into which they were born (PERLMAN, 2010, p. 307).

\begin{tabular}{l|c|c|c|c|c|c} 
(C) Rev. Educ. Perspec. & Viçosa, $M G$ & v.8 & n.3 & p.414-425 & set./dez. 2017 & eISSN 2178-8359 \\
\hline
\end{tabular}


Observing the urban scene and growing up in relation to people with a better quality of life, with a good lifestyle, shapes the internalised concept of the world in another way than growing up on the countryside and moving to the city. Inequality, exclusion and worthlessness are probably elementary aspects of the internalised concept of the world of the children' and grandchildren' view of their identity:

Each generation has faced different challenges. For the original migrants, the move to the city, the exchange of rural poverty for urban poverty, and developing the ability to survive in the new milieu was the challenge. It was in itself a major leap forward to establish a bridgehead or toehold in the big city. Their collective struggles created a sense of community solidarity not shared by the following generations.

For the children, born in the city, the quest was for higher education, for getting out of the favelas, and for a sense of recognition and respect. In the grandchildren's generation, educational attainment is high; over half are living in legal, legitimate neighbourhoods; and the level of consumption of household goods is close to the municipal average. Their particular challenges are finding work (over half are unemployed), avoiding being killed, and finding respect (PERLMAN, 2010, p. $339)$.

The different challenges of each generation are based on the implication of the social surrounding - which is transformed by new technological developments, demographical changes, globalisation, etc. - and the internalised concept of the world, that is shaped by the social surrounding and the Subject's ability to sense the world. Exemplarily, a closer look at the challenge to find respect will be taken, because it is mentioned as challenge by the children' and grandchildren' generation of the original interviewees; in other words: it is mentioned by those who were born and grew up in urban areas, in Favelas in Rio de Janeiro, whose reference group are the people of the formal part of the city, the rich people, and not the people from the Brazilian countryside (PERLMAN, 2010, p. 161).

To be respected means to be somebody, means to be a person, to be seen as an individual with own wishes, abilities and desires. It means to be a Subject and to be threaten as a Subject with an own individual concept of the world. That implies to be allowed to interact with the social surrounding according to the individual's internalised concept, considering the rule of law and the dialectic of human and nature. To find respect, to say: respect is a challenge of the two generations that grew up in Favelas, refers to the fact, that the internalised concept of the world of these people is denied. It is denied to be somebody, to be Subject. The Portuguese language, especially the people that are fighting for respect, use the word gente to describe their right to have an individual concept of the world. Gente (engl. people) is not only the expression to be somebody, but also to be respected as somebody, to be seen as an equal individual with the right to be part of society, to be part of the social surrounding and to be allowed to have an own internalised concept of the world, that implies all aspects

\begin{tabular}{l|l|l|l|l|l|l} 
(C) Rev. Educ. Perspec. & Viçosa, $M G$ & v.8 & n.3 & p.414-425 & set./dez. 2017 & eISSN 2178-8359 \\
\hline
\end{tabular}


mentioned before. "And both highlight the ongoing multigenerational struggle to 'become gente' - literally to become a person, to move from invisible to visible or from a nonentity to a respected human being" (PERLMAN, 2010, p. 7).

Becoming gente is a challenge between the people that are threaten as gente and the ones that are not considered as such. But to become gente in a world that is ruled by the decisions and definitions of the ones who are gente means to adapt to the social surrounding, to become part of the social surrounding of those who are gente, to develop coping mechanisms to adapt to the life of gente. One example is presented by Perlman in the introduction when she talks about the story of Patricia. Patricia is the granddaughter of one of the original interviewees who moved from the rural to the urban area in the 1960s (PERLMAN, 2010). Patricia grew up in Nova Brasília. She says about herself: "I live in Copacabana now - it's another world entirely. I will probably never go to Nova Brasília again. It's very dangerous” (PERLMAN, 2010, p. 3).

Furthermore, she describes that she did not see her grandfather for 14 years (PERLMAN, 2010), but that she remembers her life in Nova Brasília and her grandfather very well. Patricia did the jump from the Favela to the formal city, she achieved the goal to become gente, but aware of her Socialisation, of her internalised concept of the world, she developed coping mechanisms to supress her origin and to adapt to her new social surrounding. Becoming gente was possible by supressing and covering parts of her identity: the parts shaped during her childhood. An indication is the fact that she did not go to Nova Brasília for over 14 years, that she did not see her grandfather for over 14 years. Going back to Nova Brasília does not only mean to go to a very dangerous area ruled by drug lords, but to confront herself with her own origins, with her own identity, with her internalised concept of the world, and this confrontation can be painful, therefore humans develop coping mechanisms to avoid the implicated confrontation.

The idea "If given half a chance, any of them could become gente" (PERLMAN, 2010, p. 144) does imply the fact that people need to deny, supress, cover at least parts of the own internalised concept of the world, to deny being who they are - at least within the current circumstances. Considering this, the right to education can not only be understood as the legal right to education but has to be seen as the right to be gente, the right to live, interact and participate in society and be allowed to have an own identity, an own internalised concept of the world.

The right to mediate between the social surrounding and the internalised concept of the world may be the key to enable the Subject to participate in society as an individual human being, a

\begin{tabular}{l|l|l|l|l|l|l} 
(C) Rev. Educ. Perspec. & Viçosa, $M G$ & v.8 & n.3 & p.414-425 & set./dez. 2017 & eISSN 2178-8359 \\
\hline
\end{tabular}


human being that is seen as gente. But to do so, it is necessary to accept each human being as an individual, as a Subject, as gente, with an own internalised concept of the world. It means to accept diversity in society, to stop forcing people to adapt to circumstances developed by the most powerful ones, to stop forcing people to develop coping mechanisms. Following this argumentation, the right to education can not only be limited to the right to attend school, but must be extended to the right to be gente, the right to mediate between the social surrounding and the own internalised concept of the world, the right to understand and interact with the world according to the internalised concept.

Having, once again, a look at the Facebook post mentioned at the beginning, it is now maybe possible to have a better understanding of the expression by Débora Bertoldi and the comments related to the post of interest. Growing up on the countryside close to Campinas, being a landowner and depending on employees who take care of her territory and "sabem de trabalhar com a enxada" does not only pose a risk to her lifestyle and quality of life when there are not enough people willing to work for her, but it is an expression of her internalised concept of the world, the way she understands the world to be. Her letter and her fear, expressed in the letter, can be taken as an "artefact" (BUCHMANN; KELL, 2013, p. 207), an expression of her internalised concept of the world, an expression of becoming aware of the changes in the social surrounding. The question is: How does she deal with the realisation of the new circumstances in the social surrounding? Does she develop any coping mechanism? Does she modify her social surrounding? The only thing we can be sure about is that her internalised concept of the world will always be part of her identity and will always influence her interaction with the social surrounding.

\section{REFERENCES}

ARENDT, Hannah. Vom Leben des Geistes. Das Denken. München: Piper, 1971.

BUCHMANN, Ulrike. Vom Tagging zur Domäne. Neue curriculare Wege zur Alphabetisierung und Grundbildung Jugendlicher. Vierteljahresschrift für Heilpädagogik und ihre Nachbargebiete (VHN), v. 4, 82. Jg., München: Ernst Reinhardt Verlag, p. 294$310,2013$.

BUCHMANN, Ulrike; DIEZEMANN, Eckart. Inklusives Übergangssystem: Wie sie werden, was sie sein könnten. Erkenntnistheoretische Bestimmung und empirische Grundlagen von Bildungsprojekten in Übergängen beruflicher Bildung. Zeitschrift für Berufs- und Wirtschaftspädagogik (ZBW), Bd. 110, Heft 2, p. 257-273, 2014.

\begin{tabular}{l|l|l|l|l|l|l} 
(C) Rev. Educ. Perspec. & Viçosa, $M G$ & v.8 & n.3 & p.414-425 & set./dez. 2017 & eISSN 2178-8359 \\
\hline
\end{tabular}


BUCHMANN, Ulrike; GIMBEL, Katharina. Zur Dramatik der kulturellen Bildung - als sprachliche Tautologie zugleich wissenschaftlicher Referenz für Curricula mit Inklusionsanspruch. Si:So, Siegen, 1/2015, 20. Jg., p. 68-79, 2015.

BUCHMANN, Ulrike; KELL, Adolf. Bildung, Architektur, Künste. Ein auf(zu)klärender Zusammenhang - oder das Bauhaus als Curriculum? Subjektentwicklung und

Sozialraumgestaltung als Entwicklungsaufgabe: Szenarien einer transdisziplinären Realutopie. Frankfurt am Main: G.A.F.B., p. 201-216, 2013.

GIMBEL, Katharina. UnVermittelt: Benachteiligungen als Herausforderung für die berufsbildungswissenschaftliche Forschung - Ästhetische Zugänge an Berufskollegs? WEIß, Gabriele. Kulturelle Bildung - Bildende Kultur. Bielefeld: transcript, 2017.

HOLZKAMP, Klaus. Lernen. Subjektwissenschaftliche Grundlegung. Frankfurt am Main: Campus Verlag, 1985.

LISOP, Ingrid; HUISINGA, Richard. Arbeitsorientierte Exemplarik. Subjektbildung Kompetenz - Professionalität. Frankfurt am Main: G.A.F.B., 2004.

PERLMAN, Janice E. Favela: Four Decades of Living on the Edge in Rio de Janeiro. New York and Oxford: Oxford University Press, 2010.

\section{About the Authors}

Jan Breuer: Faculdade de Educação, Departamento de Educação Profissional da Universidade de Siegen. Rank: Wissenschaftlicher Mitarbeiter. E-mail: jan.breuer@uni$\underline{\text { siegen.de }}$

Ulrike Buchmann: Faculdade de Educacao, Departamento de Educação Profissional da Universidade de Siegen. Rank: Professora e Doutora. E-mail: ulrike.buchmann@unisiegen.de

\begin{tabular}{l|c|c|c|c|c|c} 
(C) Rev. Educ. Perspec. & Viçosa, $M G$ & v.8 & n.3 & p.414-425 & set./dez. 2017 & eISSN 2178-8359 \\
\hline
\end{tabular}

